\title{
Vertical Distribution, Persistence, and Activity of Entomopathogenic Nematodes (Nematoda: Heterorhabditidae and Steinernematidae) in Alfalfa Snout Beetle- (Coleoptera: Curculionidae) Infested Fields
}

\author{
CAROL S. FERGUSON, ${ }^{1}$ PETER C. SCHROEDER, ${ }^{2}$ AND ELSON J. SHIELDS \\ Department of Entomology, Cornell University, Ithaca, NY 14853
}

\begin{abstract}
Environ. Entomol. 24(1): 149-158 (1995)
ABSTRACT The vertical movement, persistence, and activity of four isolates of entomopathogenic nematodes, Heterorhabditis bacteriophora Poinar (Oswego), Heterorhabditis bacteriophora Poinar (NC), Steinemema carpocapsae (Weiser) (NY001), and an undescribed Steinernema species (NY008-2E), were evaluated for 24 mo at field locations in northern New York. Nematodes were released into three alfalfa fields naturally infested with alfalfa snout beetle, Otiorhynchus ligustici (L.). Each field differed in soil type and soil textural composition: silt loam, sandy loam, and loamy sand. Nematodes were recovered from soil using trap insects, Galleria mellonella larvae, and their vertical distribution was monitored at $5-\mathrm{cm}$ intervals to depths of $20 \mathrm{~cm}$ for Steinemema species and $35 \mathrm{~cm}$ for Heterorhabditis species.

All nematodes persisted (no significant reduction in percentage of infection of $G$. mellonella) for 6 mo after the initial application in all soil types. However, by the end of the second growing season ( 17 mo after application), all nematodes showed significant reductions in infection rates of $G$. mellonella except $H$. bacteriophora (Oswego) which showed high levels of infection for 24 mo. Nematode vertical movement was affected by soil type and varied by isolate. S. carpocapsae (NY001) and Steinernema sp. (NY008-2E) remained primarily in soil depths $<15 \mathrm{~cm}$, whereas both heterorhabditids dispersed to soil depths of $35 \mathrm{~cm}$. Vertical movement of $H$. bacteriophora (Oswego) was greatest in loamy sand and vertical movement of Steinernema sp. (NY008-2E) was greatest in sandy loam. Percentage of infection of G. mellonella by $H$. bacteriophora (Oswego) and S. carpocapsae (NY001) was significantly correlated with rising soil temperatures in early spring. $H$. bacteriophora (Oswego) and $S$. carpocapsae (NY001) infected $G$. mellonella larvae in the field at soil temperatures between 15 and $18^{\circ} \mathrm{C}$. Steinemema sp. (NY008-2E) infected $G$. mellonella larvae in the field at soil temperatures between 13 and $15^{\circ} \mathrm{C}$.
\end{abstract}

KEY WORDS Otiorhynchus ligustici, alfalfa, entomopathogenic nematodes

THE ALFALA SNOUT BEETLE, Otiorhynchus ligustici (L.), was first recorded in New York state in 1896 near Oswego, NY (Palm 1935, York et al. 1971 ), and presently infests $\approx 200,000$ ha in eight counties of northern New York state and southeast Ontario, Canada (York 1974, Bechinski \& Hescock 1990). Alfalfa snout beetle larvae feed on and often sever the tap root of alfalfa plants, resulting in yield reduction and ultimately stand loss (Lincoln \& Palm 1941, Mellors 1977, Leonard 1988). Current control strategies, crop rotation and insecticides, against the alfalfa snout beetle have not been effective (Willson et al. 1976, Leonard 1988).

The use of entomopathogenic nematodes against soil-inhabiting pests has been documented

\footnotetext{
1 Current address: Biology Department, Southem Oregon State College, Ashland, OR 97520 .

${ }^{2}$ Current address: Department of Entomology, New York State Agricultural Experiment Station, Cornell University, Geneva, NY 14456 .
}

(Gaugler 1981, Kaya 1985, Klein 1988, Capinera \& Epsky 1992). The biology of the alfalfa snout beetle and the ecology of the alfalfa ecosystem make the use of entomopathogenic nematodes a potentially viable control tactic. The soil, where the alfalfa snout beetle spends the majority of its 2-yr life cycle (Lincoln \& Palm 1941, Mellors 1977), is the natural reservoir of entomopathogenic nematodes (Gaugler 1981, Klein 1990). High-host density leads to increased contact between nematodes and uninfected hosts (Fuxa 1987) and population densities of 5 million alfalfa snout beetles per hectare (2 million per acre) are common for this parthenogenetic pest (unpublished data). Alfalfa fields harbor a diversity of soil insects that could potentially serve as additional hosts for entomopathogenic nematodes (Kaya 1990a). Alfalfa ground cover limits moisture and temperature fluctuations in the soil that may affect nematode survival (Molyneux 1985, Kaya 1990a, Kung et al. 1991). 


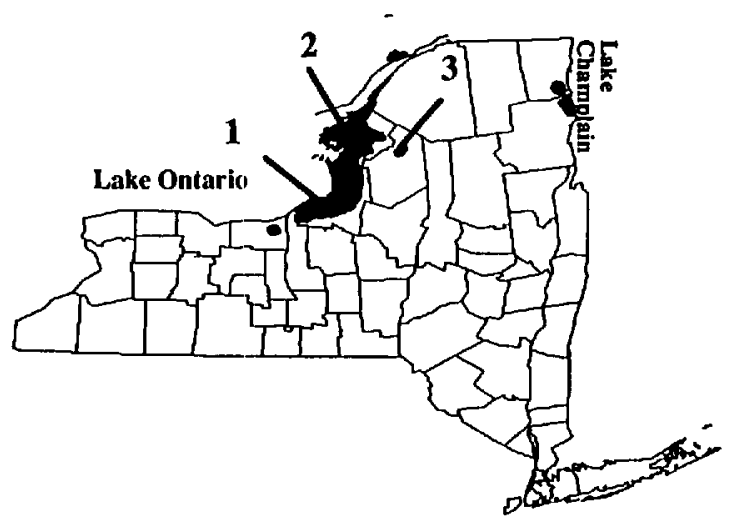

Fig. 1. New York state map showing current range of alfalfa snout beetle infestation (dark area) and the three field site locations used to study nematode vertical distribution and persistence. Sites are represented by number: site 1 (silt loam), site 2 (sandy loam), site 3 (loamy sand).

Weevils (Coleoptera: Curculionidae) in general are highly susceptible to entomopathogenic nematodes (Klein 1990). The successful control of the black vine weevil, Otiorhynchus sulcatus (F.), a close relative of the alfalfa snout beetle, with Heterorhabditis nematodes has been demonstrated in the greenhouse (Bedding \& Miller 1981, Simons 1981, Georgis \& Poinar 1984, Stimman et al. 1985) and in the field (Shanks \& Agudelo-Silva 1990). Recent laboratory bioassays have documented the pathogenicity of steinernematid and heterorhabditid nematodes to alfalfa snout beetle larvae. Potted alfalfa plants infested with alfalfa snout beetle larvae and treated with infective juveniles of Heterorhabditis bacteriophora showed significantly less root damage by alfalfa snout beetle larvae than plants not treated with nematodes (Schroeder et al. 1994).

Despite many successes, field trials using entomopathogenic nematodes against soil-inhabiting pests have not produced consistent control (Kaya 1990a). Most researchers recognize the need better to understand nematode ecology before attempting long-term suppression of a pest in the field (Fuxa 1987, Kaya 1990a). Therefore, we evaluated the vertical distribution, persistence, and activity of several entomopathogenic nematode isolates in alfalfa fields containing different soil types in northern New York state.

\section{Matcrials and Methods}

Study Site. Three study sites were established in commercial alfalfa fields within the alfalfa snout beetle infested area of northern New York (Fig. 1). All study sites were naturally infested with alfalfa snout beetle and were selected based on soil type. Site 1 consisted of a 4-yr-old alfalfa stand on silt loam located near Mexico in Oswego County, site 2 consisted of a 3 -yr-old alfalfa stand on sandy

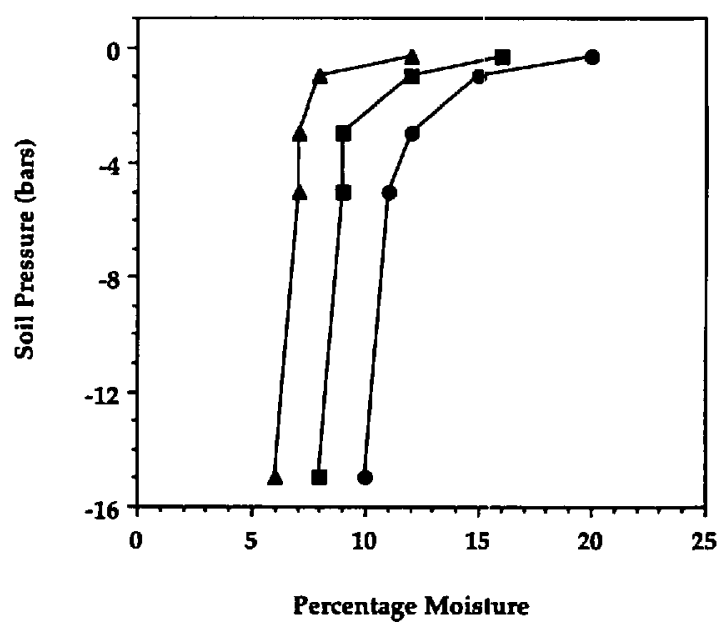

Fig. 2. Soil moisture retention curves for silt loam (circle), sandy loam (square), and loany sand (triangle) soils collected at site 1 , site 2 , and site 3 , respectively.

loam located near Carthage in Jefferson County, and site 3 consisted of a 3-yr-old alfalfa stand on loamy sand located near Croghan in Lewis County. Soil from each site was sampled before nematode release and analyzed for textural composition, $\mathrm{pH}$, and moisture retention characteristics by the Soil Testing and Nutrient Analysis Laboratory at Cornell University, Ithaca, NY. Textural classifications were $27.7 \%$ sand, $60.8 \%$ silt, $11.5 \%$ clay (silt loam), and $\mathrm{pH} 6.4$ at site $1 ; 59.9 \%$ sand, $33.8 \%$ silt, $6.3 \%$ clay (sandy loam), and $\mathrm{pH} 5.8$ at site 2 ; and $78.1 \%$ sand, $19.0 \%$ silt, $2.9 \%$ clay (loamy sand), and $\mathrm{pH}$ 6.5 at site 3 . The moisture-retention curves for the soils collected at each site revealed differences in the water-holding capacity of each soil (Fig. 2). Also, 10 soil samples were taken with a hand trowel from random locations in each site to a depth of 5 $\mathrm{cm}$ to determine the presence of naturally occurring nematodes. These soil samples were placed in plastic containers with 10 mature wax moth larvae, Galleria mellonella (L.) (Ja-Da Bait, Antigo, WI), as trap insects (Bedding \& Akhurst 1975). G. mellonella were stored at $23^{\circ} \mathrm{C}$ and observed for nematode infection after $4 \mathrm{~d}$. Based on these soil samples, no natural populations of entomopathogenic nematodes were detected in the field sites.

Nematode Culture and Application. Four isolates of entomopathogenic nematodes were used in our field studies. Three nematodes, $H$. bacteriophora Poinar (Oswego), Steinernema carpocapsae (Weiser) (NY001), and an undescribed Steinernema sp. (NY008-2E) were isolated in the fall of 1990 from soil in Oswego County, New York, using G. mellonella as trap insects (Bedding \& Akhurst 1975, Woodring \& Kaya 1988). The fourth nematode, Heterorhabditis bacteriophora (Poinar) (NC), was obtained in January 1991 from Hydrogarden (Colorado Springs, CO) as infective juveniles in moist polyethylene foam. All nematodes 
Table 1. Nematode application dates and application rates in 1991

\begin{tabular}{lcc}
\hline \multicolumn{1}{c}{$\begin{array}{c}\text { Entomopathogenic nematode } \\
\text { species (strain) }\end{array}$} & $\begin{array}{c}\text { Applica- } \\
\text { tion date } \\
\text { (Julian } \\
\text { date) }\end{array}$ & Application rate \\
\hline H. bacteriophora (Oswego) & 134 & $16.8 \times 10^{9}$ \\
I. bacteriophora (NC) & 141 & $5.4 \times 10^{9}$ \\
S. carpocapsae (NY001) & 143 & $3.0 \times 10^{9}$ \\
Steinemena sp. (NY008-2E) & 147 & $2.0 \times 10^{9}$ \\
\hline
\end{tabular}

a Infective juveniles per hectare.

were regularly cultured in vivo at $23^{\circ} \mathrm{C}$ in G. mellonella larvae. In May 1991, infective juveniles of each nematode species were collected in modified White traps (White 1927, Woodring \& Kaya 1988) during a $72-\mathrm{h}$ period as they emerged from $\mathrm{G}$. $\mathrm{mel}$ lonella cadavers. Nematodes were examined under a dissecting scope to determine the percentage of nematodes alive, and nematode density was determined by serial dilution. Infective juveniles of each nematode species were placed by pipette into sterile $75-\mathrm{ml}$ culture flasks containing $100 \mathrm{ml}$ distilled water and held at $23^{\circ} \mathrm{C}$ for $12-24 \mathrm{~h}$ before being applied to field plots.

At each field site, the infective juveniles of each nematode species were suspended in 8 liters of water and applied to $1.5-\mathrm{m}^{2}$ plots using a watering can. Plots were replicated four times and arranged in a $4 \times 4$ Latin-square design at each site. Plots were separated from adjacent plots by $2.4 \mathrm{~m}$ of untreated area. Nematodes were applied between 14 and 27 May 1991 at rates ranging from 2 to 16 billion infective juveniles per hectare (Table 1). The application rates of the four nematode isolates reflect differences in infective juvenile production at $23^{\circ} \mathrm{C}$. A portable data recording device (Easy Logger EL-824 equipped with TP-10 or ES-060 thermistor temperature probes, Omnidata, Logan, UT) monitored average hourly soil temperatures 5 $\mathrm{cm}$ below the soil surface at each field site. The surface soil temperatures at the three field sites ranged between 15.5 and $23^{\circ} \mathrm{C}$ when nematodes were applied.

Nematode Vertical Distribution and Persistence. Soil samples were taken monthly after nematode application to assess the vertical movement of nematodes at the three field sites and to assess the persistence of infective nematodes from June to November 1991. Additional soil samples were taken 17 and 24 mo after nematode application to determine long-term persistence of the nematodes. Samples consisted of four 1.9-cm-diameter cores of soil taken from each plot at each location. Soil cores were taken to a maximum depth of 20 $\mathrm{cm}$ in the plots receiving steinernematid nematodes and to a maximum depth of $35 \mathrm{~cm}$ in plots receiving heterorhabditid nematodes. At each site, cores were separated into 5 -cm-long sections $(0$ $5,5-10,10-15,15-20,20-25,25-30$, and $30-35$ $\mathrm{cm})$, and the sections from the same depth from plots treated with the same nematode were combined, thoroughly mixed, and reapportioned into 15 individual $30-\mathrm{ml}$ plastic cups in the laboratory. A single G. mellonella larva was placed on the surface of the soil in each 30-ml cup. The cups were capped, turned upside down on trays, and stored inside plastic bags in a dark environmental chamber at $23^{\circ} \mathrm{C}$. After $4 \mathrm{~d}$, dead G. mellonella were examined for nematode infection by observing the condition and color of the cadaver (Poinar 1984). When infection could not be confirmed by visual inspection, G. mellonella cadavers were dissected and examined for nematodes under a light microscope or set up on individual White traps and examined for emerging infective stage (dauer) nematodes 4-7 d later.

Differences in the percentage of infected $G$. mellonella infected with nematodes across soil depths between nematode isolates and soil types were analyzed using analysis of variance (ANOVA) of polynomial contrasts (Rowell \& Walters 1976). If the effects of nematode isolates were significant $(P<0.05)$, orthogonal contrasts were constructed to test for differences between the vertical infection rates of the two heterorhabditid strains, the two steinernematid species, and the two nematode families (heterorhabditid and steinernematid).

Differences in the percentage of nematode infected G. mellonella between nematode isolates and soil depth across sample dates were analyzed as a repeated measures ANOVA (SYSTAT 1992). Separate analyses were conducted to test for differences in the percentage of nematode-infected G. mellonella between all samples taken in 1991 and between samples taken at 2,6,17, and 24 mo after nematode release.

Nematode Activity. Beginning in April 1992 and once a month thereafter, two caged G. mellonella were placed in each plot originally treated with nematodes in May 1991 to determine when nematodes first began to infect a host at $5 \mathrm{~cm}$. Each G. mellonella cage was filled with soil from the field plot being sampled and a single G. mellonella larva was placed inside the cage (Fig. 3). Cages were buried to a depth of $5 \mathrm{~cm}$ within the plots. After 5-7 d, the G. mellonella were checked for nematode infection. Average hourly soil temperatures $5 \mathrm{~cm}$ below the soil surface were recorded for the sample period (i.e., the number of days the G. mellonella traps were buried in the soil) at each field site using a portable data recording device. The percentage of $G$. mellonella in traps infected by each nematode species was regressed (SuperANOVA, Abacus Concepts 1990) against the average daily soil temperatures for each sample period, to determine if nematode activity in the field correlated with field soil temperature.

\section{Results}

Nematode Vertical Distribution. All nematode isolates were recovered at all depths to $20 \mathrm{~cm}$. The 

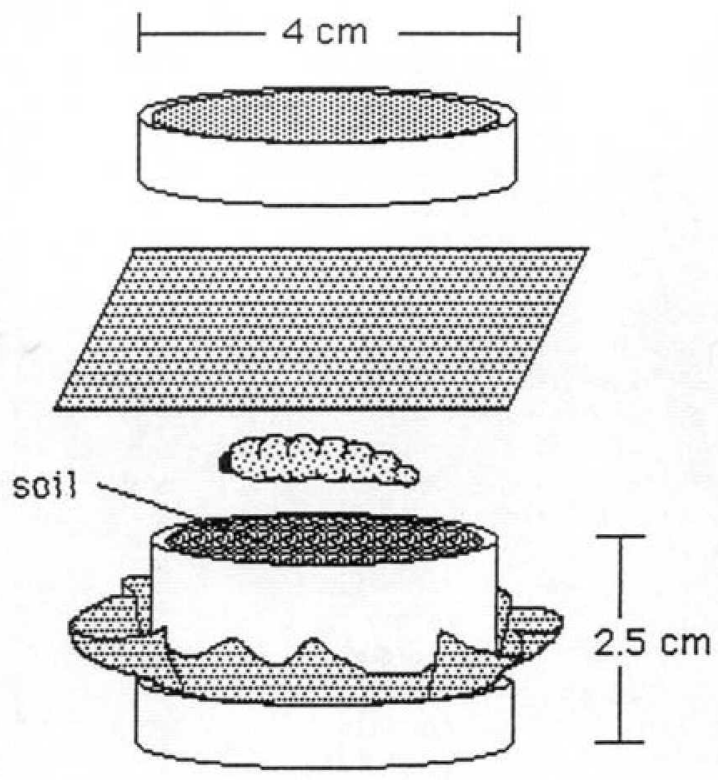

Fig. 3. Schematic diagram of $G$. mellonella cage used to monitor nematode activity in the field. Each cage consisted of a polyvinyl chloride pipe (3-cm diameter, $2.5 \mathrm{~cm}$ long) covered at both ends with nylon screen (mesh size, $2 \mathrm{~mm}$ ). Screen was secured to the cage with a $4-\mathrm{cm}-$ diameter ring of polyvinyl chloride pipe.

heterorhabditid plots were sampled to a depth of $35 \mathrm{~cm}$ and both isolates were recovered at the maximum sample depth (Fig. 4 A-D), although $H$. bacteriophora (Oswego) was recovered at these depths only in loamy sand (data not shown). In general, percentage of infection of G. mellonella by nematodes decreased with soil depth for all nematode isolates. Vertical infection rates of $G$. mellonella for soil depths to $20 \mathrm{~cm}$ significantly differed between nematode isolates $(F=50.225$; df $=3,59 ; P<0.0001)$. These vertical infection rates were best described by quadratic polynomials $(F$ $=23.237 ; \mathrm{df}=3,59 ; P<0.0001$ ), suggesting that nematode infection changed in a curvilinear fashion across depths of soil. Based on the orthogonal comparisons, vertical infection rates of $G$. mellonella for soil depths to $35 \mathrm{~cm}$ were not significantly different $(F=1.405 ; \mathrm{df}=1,59 ; P=0.241)$ between the two heterorhabditids, H. bacteriophora (Oswego) and $H$. bacteriophora (NC). However, vertical infection rates of $G$. mellonella for soil depths to $20 \mathrm{~cm}$ differed between the heterorhabditids and steinemematids $(F=49.581$; $\mathrm{df}=1$, 59; $P<0.0001)$ and between Steinernema sp. (NY008-2E) and S. carpocapsae (NY001) $(F=$ 20.142; df $=1,59 ; P<0.0001$ ). Infection of $G$. mellonella by S. carpocapsae (NY001) occurred primarily in the first $5 \mathrm{~cm}$ of soil and decreased rapidly at deeper soil layers (Fig. 4D), whereas infections by $H$. bacteriophora (Oswego), H. bacteriophora (NC), and Steinernema sp. (NY008-2E) peaked at soil depths between 5 and $20 \mathrm{~cm}$ (Fig.
4 A-C, respectively), suggesting greater vertical movement by these nematodes compared with $S$. carpocapsae (NY001) (Fig. 4D).

Vertical infection rates of $G$. mellonella significantly differed overall between soil types $(F=$ 3.838; $\mathrm{df}=2,59 ; P=0.027$ ). These differences were most apparent between the vertical infection rates of $G$. mellonella by $H$. bacteriophora (Oswego) $(F=3.881 ; \mathrm{df}=1,15 ; P=0.044)$ and Steinernema sp. (NY008-2E) $(F=5.612 ; \mathrm{df}=1,15$; $P=0.015)$. Percentage of infection of $G$. mellonella by H. bacteriophora (Oswego) was greater in loamy sand than silt loam and sandy loam at depths $>25 \mathrm{~cm}$ and greater in sandy loam than silt loam at soil depths between 15 and $25 \mathrm{~cm}$, suggesting a greater vertical movement of $H$. bacteriophora (Oswego) in the sandier soils (Fig. 4A). Percentage of infection of $G$. mellonella by Steinernema sp. (NY008-2E) was greater in sandy loam than loamy sand at depths between 5 and $15 \mathrm{~cm}$ (Fig. 4C). No differences in vertical infection rates between soil types were detected for $H$. bacteriophora (NC) (Fig. 4B) and S. carpocapsae (NY001) (Fig. 4D).

Nematode Persistence. All nematodes persisted, albeit some at apparently low numbers and at shallow depths, 24 mo after release (Fig. 5 A-D). In general, the percentage of infection of $G$. mellonella by each nematode isolate did not significantly change throughout the $6 \mathrm{mo}$ (May through November) following the initial nematode release $(F=1.586 ; \mathrm{df}=5,160 ; P=0.167)$. Seventeen and 24 mo after nematode release, percentage of infection of $G$. mellonella by nematodes was too low $(<20 \%)$ to determine adequately vertical infection rates for any nematode except $H$. bacteriophora (Oswego) (Fig. 5A). Twenty'-four mo after release, $H$. bacteriophora (Oswego) was recovered at all soil depths to $35 \mathrm{~cm}$ and infected G. mellonella at mean rates (across all soil types) of $>30 \%$ at soil depths between 5 and $20 \mathrm{cn}$ (Fig. 5A). $H$. bacteriophora (NC) was not recovered from soil samples from any soil type taken deeper than 10 $\mathrm{cm}$ at $17 \mathrm{mo}$ or later after nematode release (Fig. 5B). Both steinernematid nematodes were recovered 24 mo after the initial release but infected $>20 \%$ of G. mellonella (Fig. 5 C-D). Steinemema sp. (NY008-2E) was recovered from soil depths between 5 and $20 \mathrm{~cm}$ (Fig. 5C) and S. carpocapsae (NY001) was recovered only between 0 and $5 \mathrm{~cm}$ (Fig. 5D) 24 mo after the initial release.

Nematode Activity. Percentage of infection of G. mellonella by $H$. bacteriophora (Oswego) and S. carpocapsae (NY001) significantly correlated with mean soil temperatures during the sample period H. bacteriophora (Oswego): $F=20.158$; $\mathrm{df}=2,6$; $P=0.0022, S$. carpocapsae (NY001): $F=16.598$; $\mathrm{df}=2,6 ; P=0.0036)$. Both nematodes showed increasing activity as mean soil temperatures exceeded $15^{\circ} \mathrm{C}$ (Fig. 6). Infection rates for $H$. bacteriophora (NC) and Steinernema sp. (NY008-2E) were too low under field conditions to determine temperature relationships for these nematodes. 


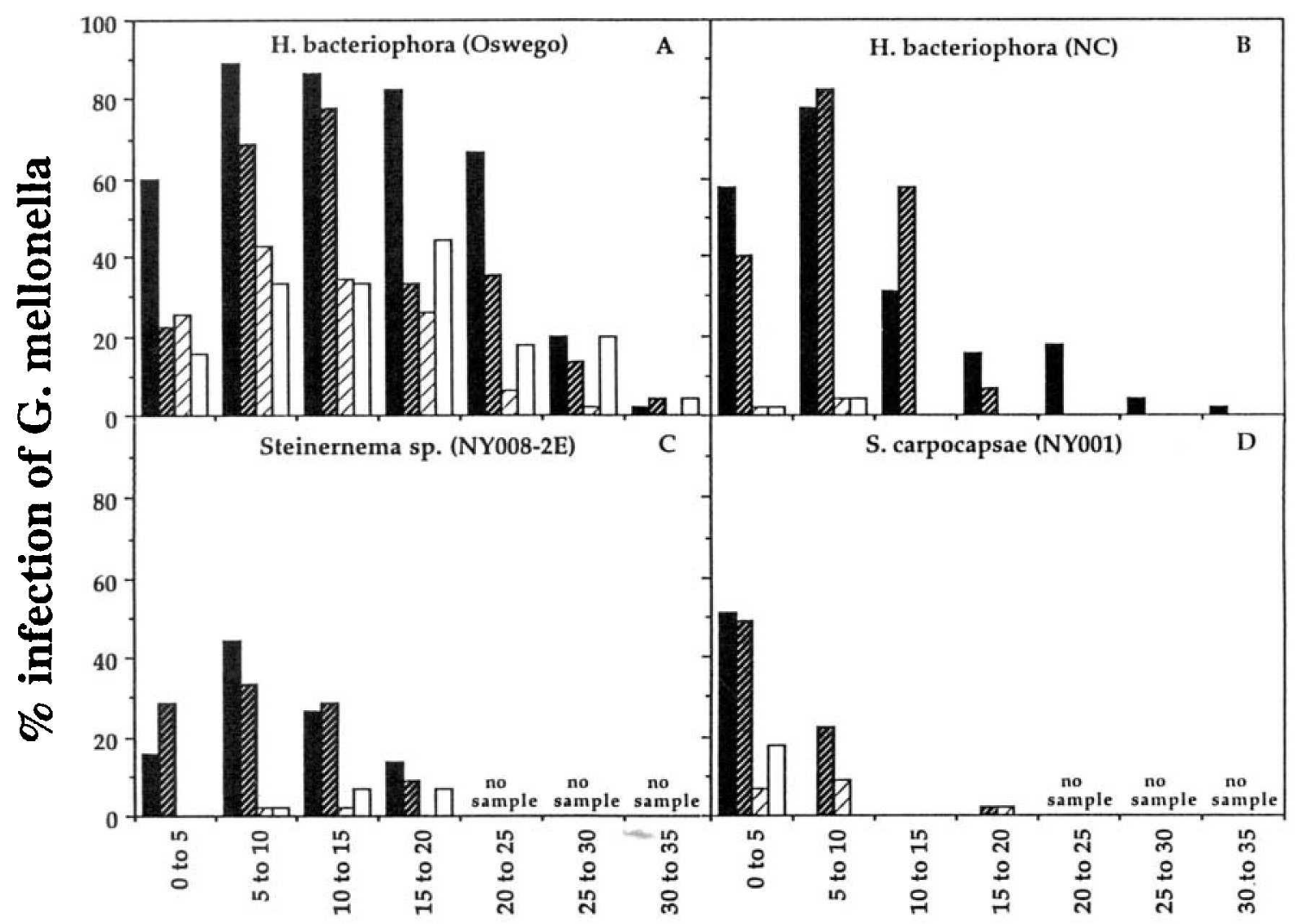

\section{Soil depth (cm)}

Fig. 4. Mean percentage of infection of $G$. mellonella at $5-\mathrm{cm}$ soil depth intervals for (A) H. bacteriophora (Oswego), (B) H. bacteriophora (NC), (C) Steinernema sp. (NY008-2E), and (D) Steinernema carpocapsae (NY001) in each field soil type: silt loam (dark column), sandy loam (hatched column), and loamy sand (light column) during the 1991 field season.

However, Steinernema sp. (NY008-2E) infected G. mellonella at mean soil temperatures as low as $13^{\circ} \mathrm{C}$. No G. mellonella in the field were infected by any nematode isolate when mean soil temperatures were $<13^{\circ} \mathrm{C}$.

\section{Discussion}

Nematode Vertical Distribution. Results from our field studies demonstrated that nematode vertical movement in soil differed between nematode species. In general, our field study corroborated laboratory studies by Moyle \& Kaya (1981) and Georgis \& Poinar (1983a) that showed S. carpocapsae remained near their release point at the soil surface. The tendency for S. carpocapsae (NY001) to remain near the soil surface may reflect the host-searching strategy of this nematode species (Gaugler et al. 1989, Barbercheck \& Kaya 1991, Kaya et al. 1993, Kaya \& Gaugler 1993). Both heterorhabditids used in our study, $H$. bacteriophora (Oswego) and H. bacteriophora (NC), infected a higher proportion of $G$. mellonella at soil depths between 15 and $20 \mathrm{~cm}$ in sandy loam and loamy sand than either steinernematid species, indicating greater vertical distribution by the heterorhabditids (Georgis \& Poinar 1983b, Barbercheck \& Kaya 1991). However, differences in vertical distribution were also detected between the two strains of $H$. bacteriophora in sandy loam and loamy sand. $H$. bacteriophora (Oswego) infected $>50 \%$ of G. mellonella to depths of $25 \mathrm{~cm}$, whereas $H$. bacteriophora (NC) infected $>50 \%$ of $G$. mellonella only to depths of $10 \mathrm{~cm}$. Under laboratory conditions using sandy loam soil, Georgis \& Poinar (1983b) found significant differences between the patterns of migration by strains of heterorhabditids and Schroeder \& Beavers (1987) documented differences between the vertical movement of $H$. heliothidis (none found below $15 \mathrm{~cm}$ from the soil surface) and H. bacteriophora in soil columns containing sandy soil. These differences may reflect strain-specific dispersal behavior or host-searching strategies (Gaugler et al. 1991, Kaya \& Gaugler 1993). The differences between the vertical distribution of the heterorhabditids used in our study 


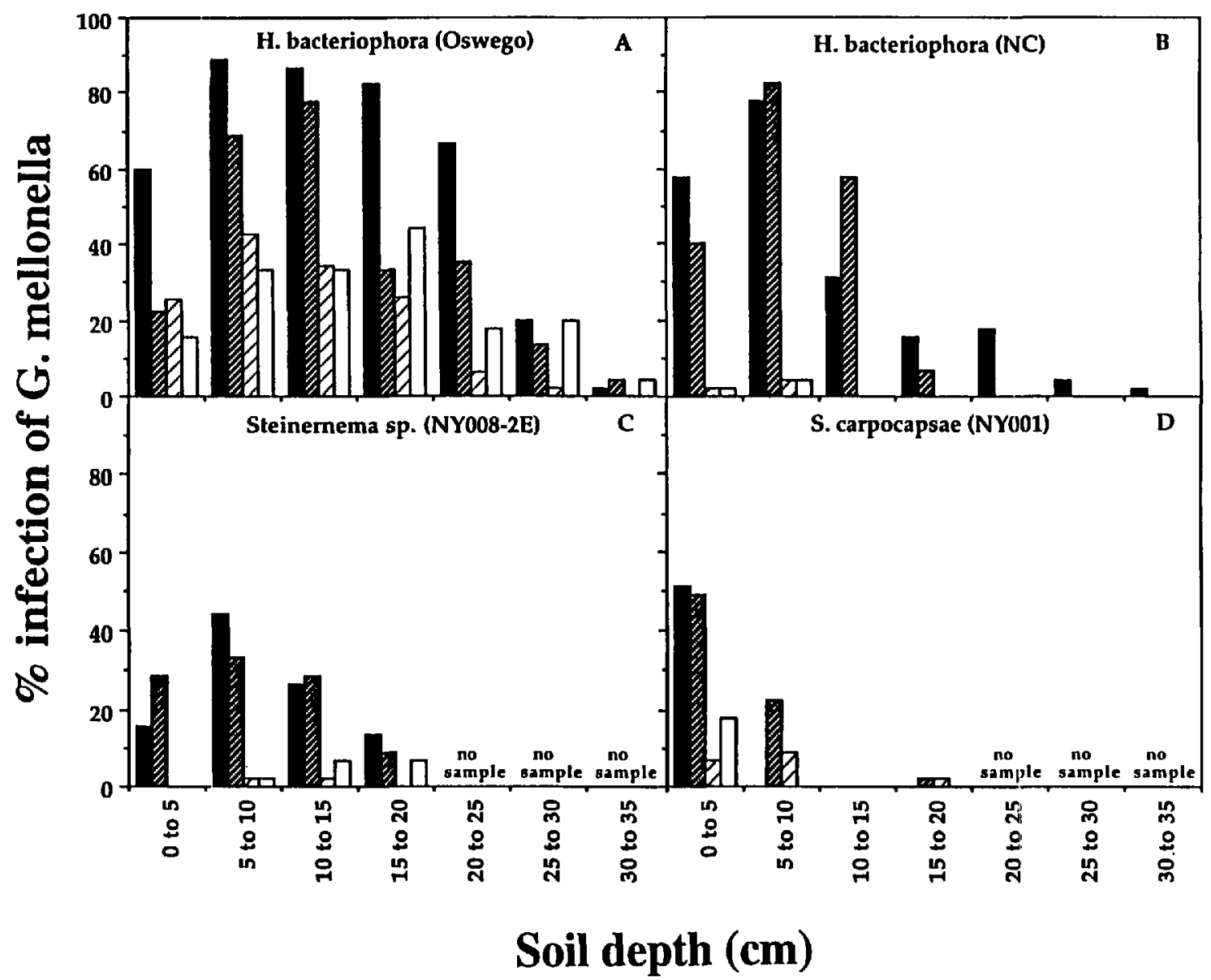

Fig. 5. Mean percentage of infection of G. mellomella at 5-cm soil depth intervals for (A) H. bacteriophora (Oswego), (B) H. bacteriophora (NC), (C) Steinernema sp. (NY008-2E), and (D) Steinemema carpocapsae (NY001) at 2 mo (dark colurnn), 6 mo (dark hatched column), 17 mo (light hatched column), and 24 mo (light column) after nematode application.

may also reflect the different application rates of these nematodes to the field plots. Three times more infective juveniles of $H$. bacteriophora (Oswego) were applied to field plots than $H$. bacteriophora (NC).

Physical characteristics of each soil type, specifically pore diameter, may have influenced how far the motile infective juveniles were able to move in the soil profile (Molyneux \& Bedding. 1984, Kaya 1990a). H. bacteriophora (Oswego) showed the furthest vertical movement in loamy sand. Loamy sand has the highest sand component $(78.1 \%)$ and the lowest clay component $(2.9 \%)$ of the three soil types studied and, consequently, the largest pore diameter (Kaya 1990a). H. bacteriophora (Oswego) infected the greatest percentage of $G$. mellonella between 5 and $25 \mathrm{~cm}$ in sandy loam and loamy sand. But in silt loam, G. mellonella infections decreased rapidly at soil depths $>10 \mathrm{~cm}$. These results agree with laboratory studies by Barbercheck \& Kaya (1991) and Choo \& Kaya (1991) who re- ported similar effects of soil texture on host finding by $H$. bacteriophora.

The vertical movement of Steinernema sp. (NY008-2E) was most restricted in silt loam and probably reflects the higher clay content of this soil and its corresponding smaller diameter pores. Steinernema sp. (NY008-2E) was the largest of the four nematodes tested in our study and would, therefore, be more constrained by soil pore diameter (Molyneux \& Bedding 1984). Laboratory studies by Georgis \& Poinar (1983a,c) have documented a decrease in the percentage of infective juveniles of Neoaplectana carpocapsae ( $=$ Steinernema carpocapsae) and $N$. glaseri (=Steinernema glaseri) that are able to migrate as the clay and silt component of soil increased. In our study, S. carpocapsae resided primarily at soil depths between 0 and $10 \mathrm{~cm}$ in all soil types. These results suggest that the vertical distribution of $S$. carpocapsae was less affected by soil type as a result of the nematodes characteristic sit and wait search strategy 


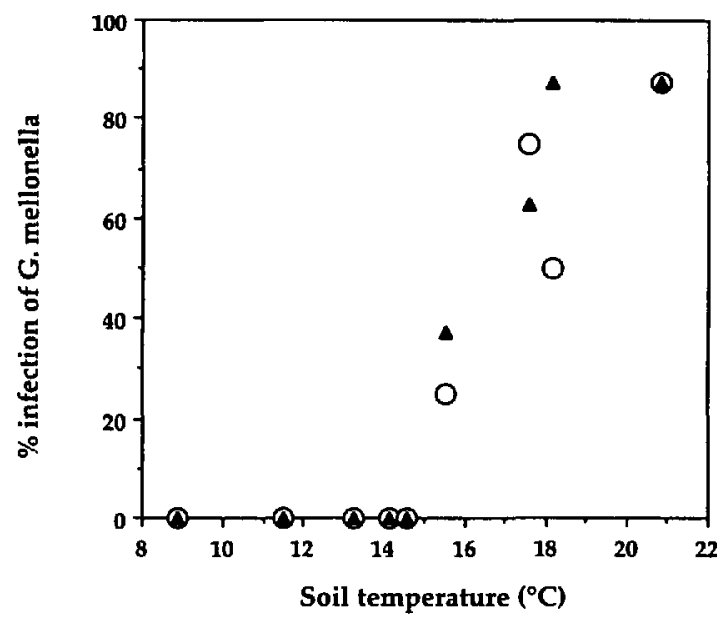

Fig. 6. Relationship between percentage of infection of $G$. mellonella and mean soil temperatures $5 \mathrm{~cm}$ below the soil surface for $H$. bacteriophora (Oswego) (circles) $\left[Y=0.834-0.176(X)+0.0878\left(X^{2}\right) ; R^{2}=0.870 ; P=\right.$ $0.0022]$ and $S$. carpocapsae (NY001) (triangles) $[Y=$ $\left.0.592-0.146(X)+0.0808\left(X^{2}\right) ; R^{2}=0.847 ; P=0.0036\right]$.

(Kaya et al. 1993). A recent laboratory study by Barbercheck \& Kaya (1991) showed that S. carpocapsae moved further than $H$. bacteriophora in clay soil filled tubes and, therefore, contrasted with the results of our field study.

Numerous abiotic (e.g., moisture gradients, temperature gradients, $\mathrm{pH}$, aeration) and biotic factors (host population density and distribution, antagonist density and distribution, plant root mass) that are not controllable under field conditions may influence the vertical movement of each nematode in each soil type (Kaya \& Gaugler 1993). This study offers additional information on the vertical movement of different species and strains of entomopathogenic nematodes in different soil types under field conditions. More importantly, all nematodes in this study survived for at least 6 mo 5$10 \mathrm{~cm}$ deep in all soil types and one strain, $H$. bacteriophora (Oswego), survived at the maximum sampling depth of $35 \mathrm{~cm}$ in loamy sand. The vertical distribution of nematodes that we tested parallels the distribution of actively feeding alfalfa snout beetle larvae (Palm 1935, Lincoln \& Palm 1941). This overlap of distributions between nematodes and host supports the potential use of entomopathogenic nematodes as a control tactic against the alfalfa snout beetle.

Nematode Persistence. The four nematodes tested in this study, H. bacteriophora (Oswego), $H$. bacteriophora (NC), Steinernema sp. (NY008-2E), and S. carpocapsae (NY001) persisted 6 mo after being applied to field locations containing different soil types. In several studies the persistence of entomopathogenic nematodes in turf, ranging from $\approx 1$ mo (Jackson \& Trought 1982, Forschler \& Gardner 1991) to $1 \mathrm{yr}$ (Klein \& Georgis 1992) has been documented. Other field studies in which the persistence of heterorhabditids in soil were investigated have shown long-term survival. Shanks \& Agudelo-Silva (1990) detected $H$. heliothidis 10 mo after application in sandy peat in cranberry bogs and Jansson et al. (1991) showed persistence of $H$. bacteriophora (HP88 strain) in gravelly loam 253 $\mathrm{d}$ after application. The current study similarly documented the persistence of entomopathogenic nematodes in field plots $1 \mathrm{yr}$ after application, which suggests that nematodes can successfully overwinter in the field at the latitude of northern New York state. Although this study offers no direct evidence of nematode recycling, long-term nematode survival may require nematode recycling.

This study offers new information on the persistence of heterorhabditids and steinernematids in different soil types under field conditions. Under laboratory conditions during a 16-wk period, Kung et al. (1990) reported that persistence of $S$. carpocapsae was significantly greater than $S$. glaseri in the four soil types tested; clay, clay loam, sandy loam, and sand. The same study also found that steinernematid nematode survival was greatest in sandy loam and sand compared with clay loam or clay. The nematode isolates used in our study also differed in their ability to persist under field conditions. One year after the nematodes were applied, $H$. bacteriophora (Oswego) infected significantly more G. mellonella $(87.5 \%)$ than $H$. bacteriophora (NC) (11.7\%), Steinernema sp. (NY008-2E) (20.8\%) or S. carpocapsae (NY001) $(14.2 \%)$ across all soil types (data not shown). The persistence of the two heterorhabditids was similar across all soil types 6 mo after the nematodes were applied. However, 17 mo after the nematodes were applied, H. bacteriophora (Oswego) infected significantly more $G$. mellonella than $H$. bacteriopho$r a(\mathrm{NC})$ in all soil types. This information suggested that the commercial heterorhabditid strain, $H$. bacteriophora (NC), may not have successfully overwintered in field plots in northern New York and may not have been suitably adapted to the local climatic conditions (Molyneux 1985, Bedding 1990).

The persistence of the heterorhabditid strains was greater than the steinernematid strains 6 mo after they were applied to different soil types. This may reflect nematode-specific search strategies (Kaya 1990b, Kaya \& Gaugler 1993) or effect of different soil types, or both. For example, S. carpocapsae (NY001) infective juveniles tend to remain near the soil surface because of their sit-andwait strategy (Kaya et al. 1993) and would, therefore, not escape the warmer and potentially detrimental soil temperatures (Molyneux 1985, Kung et al. 1991) associated with the upper $5 \mathrm{~cm}$ of soil. The other steinernematid nematode, Steinernema sp. (NY008-2E), vertically dispersed further than S. carpocapsae (NY001) and probably reflects differences in the search strategy of these 
two steinernematid nematodes. Laboratory stıdies have demonstrated differences in both the vertical (Schroeder \& Beavers 1987) and horizontal (Mannion \& Jansson 1992) movement of various steinernematid species. Also, Steinernema sp. (NY0082E) may not be able to escape detrimental soil temperatures in some types of soil because of pore diameter limitations. H. bacteriophora (Oswego) and $H$. bacteriophora (NC) dispersed to greater depths in all soil types because in part of their more active host-search strategies, possibly allowing these nematodes to escape the warm temperatures associated with the upper $10 \mathrm{~cm}$ of soil.

Nematode Activity. Infection of a host insect by entomopathogenic nematodes in the field depends on the sarre factors that influence nematode persistence; e.g., adequate moisture and temperature, absence of antagonists, favorable soil structure and texture for enhanced motility and host finding, presence of hosts (Kaya 1990a). This study offers some preliminary information on when successfully overwintered heterorhabditids and steinernematids first infect trap insects in different soil types under field conditions while considering some of the factors that influenced soil temperature in our three field locations. For example, the rate of warming of soil is determined in part by the percentage of free water in the soil (Brady 1974), therefore silt loam would warm the slowest, followed by sandy loam and loamy sand. Field locations also differed in the relative amount of ground cover, silt loam and sandy loam sites contained denser alfalfa foliage than the loamy sand site. Denser foliage cover would dampen the temperature fluctuations on the soil surface also contributing to a slower but more consistent rate of warming at these locations (Kaya 1990a). Steinernema sp. (NY008-2E) infected $G$. mellonella in silt and sandy loam before either $S$. carpocapsae (NY001) or H. bacteriophora (Oswego), when the corresponding soil temperature ranged between 13 and $15^{\circ} \mathrm{C}$. These results suggest that Steinernema sp. (NY008-2E) may have a lower temperature threshold for activity than the other nematodes tested in this study. Both $H$. bacteriophora (Oswego) and S. carpocapsae (NY001) infected G. mellonella in the field when soil temperatures were $>15^{\circ} \mathrm{C}$.

The availability of hosts would in part determine the reproductive success and subsequent survival of nematodes 1 vr after being applied in the field (Kaya 1990b, Kaya \& Gaugler 1993). The silt loam and sandy loam field sites contained older more well-established infestations of the alfalfa snout beetle, a potential primary host to entomopathogenic nematodes. While the loamy sand site contained a more recent infestation of alfalfa snout beetle and, consequently, had more distinct alternating generations of snout beetle caused by the insects' 2 -yr life cycle. In the silt loam and sandy loam field sites, we also observed an increase in density and diversity of associated soil insects; pri- marily white grubs, European chafer larvae, wireworm, dipteran larvae, lepidopteran pupae, ants, and various coleopteran adults (Curculionidae, Carabidae). Any or all of these soil insects could have served as alternate hosts for entomopathogenic nematodes (Kaya 1990b).

The three nematode strains that were originally isolated from New York soil in $2990 ; H$. bacteriophora (Oswego), S. carpocapsae (NY001), and Steinernema sp. (NY008-2E), successfully overwintered in our field plots. The nonendemic nematode, $H$. bacteriophora (NC), may not be adapted to the low soil temperatures typical of northern New York (Molyneux 1984). Laboratory studies using controlled temperature environments are being conducted to better understand the minimun and maximum temperature thresholds for nematode species to infect and reproduce in hosts. The more researchers know about the biology and ecology of entomopathogenic nematodes, i.e., infective juvenile size and motility, host-searching behavior, physiological constraints of host infection, climatic origin, the better our chances are of maximizing the efficacy of entomopathogenic nematodes against pest populations.

\section{Acknowledgments}

We thank J. Peck (Jefferson County), N. Moser (Lewis County), and J. Tompkins (Oswego County) for their cooperation and use of their land for research purposes. We also thank P. Timper (Boyce Thompson Institute, Ithacd, NY) for assisting in the identification of the entomopathogenic nematodes isolated in New York and used in this study and J. Barnard (New York State Agricultural Experiment Station, Geneva) for assistance in the statistical analysis of data. This research was funded in part by Northern New York Agricultural Development Program, Cornell College of Agriculture and Life Science and Hatch Project 139412 "Biological Control of Alfalfa Snout Beetle."

\section{References Cited}

Abacus Concepts. 1990. SuperANOVA. Abacus Concepts, Berkeley, CA.

Barbercheck, M. E. \& H. K. Kaya. 1991. Effect of host condition and soil texture on lost finding by the entomogenous nematodes Heterorhabditis bacteriophora (Rhabditida: Heterorhabditidae) and Steinernema carpocapsae (Rhabditida: Steinemematidae). Environ. Entomol. 20: 582-589.

Bechinski, E. J. \& R. Hescock. 1990. Bioeconomics of the alfalfa snout beetle (Coleoptera: Curculionidae). J. Econ. Entomol. 83: 1612-1.620.

Bedding, R. A. 1990. Logistics and strategies for introducing entomopathogenic nematode technology into developing countries, pp. 233-246. In R. Gaugler \& H. K. Kaya [eds.], Entomopathogenic nematodes in biological control. CRC, Boca Raton, FL.

Bedding, R. A. \& R. J. Akhurst. 1975. A simple technique for the detection of insect 'Jarasitic rhabditid nematodes in soil. Nematologica 2]: 109-110.

Bedding, R. A. \& L. A. Miller. 1981. Use of a nematode, Heterorhabditis heliothidis, to control black 
vine weevil, Otiorhynchus sulcatus, in potted plants. Ann. Appl. Biol. 99: 211-216.

Hrady, N. C. 1974. The nature and properties of soil. MacMillan, New York.

Capinera, J. L. \& N. D. Epsky. 1992. Potential for biological control of soil insects in the Caribbean Basin using entomopathogenic nematodes. Fla. Entomol. $75: 525-531$.

Choo, H. Y. \& H. K. Kaya. 1991. Influence of soil texture and presence of roots on host finding by Heterorhabditis bacteriophora. J. Invertebr. Pathol. 58: 279-280.

Forschler, B. T. \& W. A. Gardner. 1991. Field effcacy and persistence of entomogenous nematodes in the management of white grubs (Coleoptera: Scarabaeidae) in turf and pasture. J. Econ. Entomol. 84: $1454-1459$.

Fuxa, J. R. 1987. Ecological considerations for the use of entomopathogens in IPM. Ann. Rev. Entomol. 32: 255-281.

Gaugler, R. 1981. Biological control potential of neoaplectanid nematodes. J. Nemat. 13: 241-249.

Guugler, R., T. McGuire \& J. Campbell. 1989. Genetic variability among strains of the entomopathogenic nematode Steinernema feltiae. J. Nematol. 21: 247-253.

Gaugler, R., J. F. Camplell, \& P. Gupta. 1991. Characterization and basis of enhanced hast finding in a genetically improved strain of Steinemema carpocapsae. J. Invertebr. Pathol. 57: 234-241.

Georgis, R. G. O. Poinar, Jr. 1983a. Effect of soil texture on the distribution and infectivity of Neoaplectana carpocapsae (Nematoda: Steinemematidae). J. Nematol. 15: 308-311.

$1983 \mathrm{~b}$. Vertical migration of Heterorhabditis bacteriophora and $H$. heliothidis (Nematoda: Heterorhabditidae) in sandy loam soil. J. Nematol. 15: 652-654.

1983e. Effect of soil texture on the distribution and infectivity of Neoaplectana glaseri (Nematoda: Steinernematidae). J. Nematol. 15: 329-332.

1984. Greenhouse control of the black vine weevil Otiorhynchus sulcatus (Coleoptera: Curculionidae) by heterorhabditid and steinemematid nematodes. Environ. Entomol. 13: 1.138-1140.

Jackson, T. A. \& T. E. Trought. 1982. Progress with the use of nematodes and bacteria for the control of grass grubs, pp. 103-106. In Proceedings, 35th New Zealand Weed and Pest Control Conference, Hamilton, New Zealand, 9-12 August 1982. New Zealand Weed Control Conference, Wellington.

Jansson, R. K., S. H. Lecrone \& R. Gaugler. 1991. Comparison of single and multiple releases of Heterorhabditis bacteriophora Poinar (Nematoda: Heterorhabditidae) for control of Cylas formicarius (Fabricius) (Coleoptera: Apionidae). Biol. Control. l: 320328.

Kaya, H. K. 1985, Entomogenous nematodes for insect control in IPM systems, pp. 283-302. In M. A. Hoy \& D. C. Herzog [eds.], Biological control in agricultural IPM systems. Academic, New York.

1990a. Soil ecology, pp. 92-115. In R. Gaugler \& H. K. Kaya [eds.], Entomopathogenic nematodes in biological control. CRC, Boca Raton, FL.

1.990b. Entomopathogenic nematodes in biological control of insects, pp. 189-198. In R. R. Baker \& P. E. Dumn [eds.], New directions in biological control: alternatives for suppressing agricultural pests and diseases. Liss, New York
Kaya, H. K. \& R. Gaugler. 1993. Entomopathogenic nematodes. Annı. Rev. Entomol. 38: 181-206.

Kaya, H. K., T. M. Burlando \& G. S. Thurston. 1993. Two entomopathogenic nematode species with different search strategies for insect suppression. Environ. Entomol. 22: 859-864.

Klein, M. G. 1988. Pest management of soil-inhabiting insects with microorganisms. Agric. Ecosys. Environ. 24: $337-350$

1990. Efficacy against soil-inhabiting insect pests, pp. 195-214. In R. Gaugler \& H. K. Kaya [eds.], Entomopathogenic nematodes in biological control. CRC, Boca Raton, Fl.

Klein, M. G. \& R. Georgis. 1992. Persistence and control of Japanese beetle (Coleoptera: Scarabaeidae) larvae with steinemematid and heterorhabditid nematodes. J. Econ. Entomol. 85: 727-730.

Kung, S. P., R. Gaugler \& H. K. Kaya. 1990. Soil type and entomopathogenic nematode persistence. J. Invertebr. Pathol, 55: 401-406.

1991. Effects of soil temperature, moisture, and relative humidity on entomopathogenic nematode persistence. J. Invertebr. Pathol. 57: 242-249.

Leonard, N. R. 1988. Integrated pest management of alfalfa, pp. D33-34. In Abstracts of 1987 projects, Fourth annual IPM Conference, 20-21 January 1988. N.Y. State Integrated Pest Management Program, Ithaca, NY.

Lincoln, C. \& C. E. Palm. 1941. Biology and ecology of the alfalfa snout beetle. Cornell Univ. Agric. Exp. Stn. Mem. 236

Mannion, C. M. \& R. K. Jansson. 1992. Movement and postinfection emergence of entomopathogenic nematodes from sweetpotato weevil, Cylas formicarius (F.) (Coleoptera: Apionidae). Biol. Control 2: 297305.

Mellors, W. K. 1977. Quantitative sampling of the larvae and adults of the alfalfa snout beetle, Otiorhynchus ligustici (L.). M.S. thesis, Comell University, Ithaca, NY.

Molyneux, A. S. 1985. Survival of infective juveniles of Heterorhabditis spp. and Steinernema spp. (Nematoda: Rhabditida) at various temperatures and their subsequent infectivity for insects. Rev. Nematol. 8: $165-170$.

Molyneux, A. S. \& R. A. Bedding. 1984. Influence of soil texture and moisture on the infectivity of Heterorhabditis sp. D1 and Steinemema glaseri for larvae of the sheep blowfly, Lucilia cuprina. Nematologica 30: $358-365$

Moyle, P. L. \& H. K. Kaya. 1981. Dispersal and infectivity of the entomogenous nematode, Neorplectana carpocapsae Weiser (Rhabditida: Steinernematidae), in sand. J. Nematol. 13: 295-300.

Palm, C. E. 1935. The alfalfa snout beetle, Brachyrhinus ligustici L. Cornell Univ. Agric. Exp. Stn. Bull. 629.

Poinar, G. O., Jr. 1984. The natural history of nematodes. Prentice-Hall, Englewood Cliffs, NJ.

Rowell, J. G. \& D. E. Walters. 1976. Analyzing data with repeated observations on each experimental unit. J. Agric. Sci. Cambridge 87: 423-432.

Sehroeder, P. C., C. S. Ferguson \& E. J. Shields. 1994. Pathogenicity of Rhabditid nematodes (Nematoda: Heterorhabditidae and Steinernematidae) to alfalfa snout beetle (Coleoptera: Curculionidae) larvae. J. Econ. Entomol. 87: 917-922. 
Schroeder, W. J. \& J. B. Beavers. 1987. Movement of the entomogenous nematodes of the families Heterorhabditidae and Steinernematidae in soil. J. Nematol. 19: 257-259.

Shanks, C. H., Jr., \& F. Agudelo-Silva. 1990. Field pathogenicity and persistence of heterorhabditid and steinernematid nematodes (Nematoda) infecting black vine weevil larvae (Coleoptera: Curculionidae) in cranberry bogs. J. Econ. Entomol. 83: 107-110.

Simons, W. R. 1981. Biological control of Otiorhynchus sulcatus with heterorhabditid nematodes in the glass house. Neth. J. Plant Pathol. 87: 149-158.

Stimmann, M. W., J. K. Kaya, T. M. Burlando \& J. P. Studdert. 1985. Black vine weevil management in nursery plants. Calif. Agric. 39: 25-26.

SYSTAT. 1992. Version 5.2. SYSTAT, Evanston, IL.

White, G. F. 1927. A method for obtaining infective nematode larvae from cultures. Science (Washington, DC) $66: 302-303$.
Willson, H. R., A. A. Muka \& G. G. Gyriseo. 1976. Alfalfa snout beetle: management practices for its suppression. Cornell Univ. Int. Bull. 1.06.

Woodring, J. L. \& J. K. Kaya. 1988. Steinemematid and heterorhabditid nematodes: a handbook of techniques. Southern Cooperative Series Bull. 331. Arkansas Agric. Exp. Stn., Fayetteville, AK.

York, A. C. 1974. Contributions to the biology of the alfalfa snout beetle, Otiorhynchus ligustici (L.). Ph.D. dissertation, Cornell University, Ithaca, NY.

York, A. C., G. G. Gyrisco \& C. E. Edmonds. 1971. The status of the alfalfa snout beetle in New York state. J. Econ. Entomol. 64: 1332-1333.

Received for publication 14 December 1993; accepted 26 August 1994. 